\title{
窒化珪素の高温特性
}

\author{
粟津 知之, 小村 修, 三宅 雅也 \\ 住友電気工業侏伊丹研究所, 开664 伊丹市昆陽北1-1-1.
}

\section{High Temperature Properties of Sintered Silicon Nitride}

Tomoyuki Awazu, Osamu Komura and Masaya Miyake

Itami Research Laboratories, Sumitomo Electric Industries, Ltd., 1-1-1 Koya-kita, Itami 664.

Received December 17, 1991

Since silicon nitride is fabricated using liquid phase sintering, sintering additives usually remain between $\mathrm{Si}_{3} \mathrm{~N}_{4}$ grains as grain boundary phases. The grain boundary phases are softened and suddenly reduce the strength of sintered body under high temperature. This phenomenon occurs more notably when grain boundary phases contain glassy ones. The condition of grain boundary phases also influences the creep property under high temperature. This paper investigates the internal friction of $\mathrm{Si}_{3} \mathrm{~N}_{4}$ sintered body, which relates to grain boundary slip and diffusion of atoms. This investigation will clarify the relationship between the conditions of grain boundary phases (ex. crystallization) and the internal friction changes. The creep properties of sintered body are also studied by analyzing the results of internal friction measurements. This will allow us to fully consider the relationship between the compasition of sintering additives and the effects of heat treatment for crystallization.

\section{I 緒言}

窒化珪素は高温構造用材料として強度と鞋性に優れ ていることからガスタービンや自動車エンジン部品へ の応用が换討されている。しかし、液相焼結というプ ロセスを行なうことから焼結助垖が粒界相として残存 し、高温罢境下ではその粒界相が軟化し、急激な強度 低下を引き起こす。この現象は粒界相がガラス状態で あるほど顥著に現われる”。また、高温でのクリーブ 特性にも粒界相の状態が非常に大きな殷梱を与える。 しかし、粒界相におけるガラス状態の評価方法は確立
されていない。一方、セラミックスの高温内部摩擦は 粒界に形成される化合物中の原子の拡散や粒界すべり など粒界の性筫に関係している2!ことが知られている。 そこで、本研究では粒界相の結晶化状態を内部摩擦に より調べて、高温内部摩擦とクリープ特性の関係を明 らかにした。さらに、焼結体中の粒界相の結晶化状熊 の内部摩擦の測定結果をもとにして、 $\mathrm{Si}_{3} \mathrm{~N}_{4}$ 焼結体のク リープ特性改善を目的とした。 


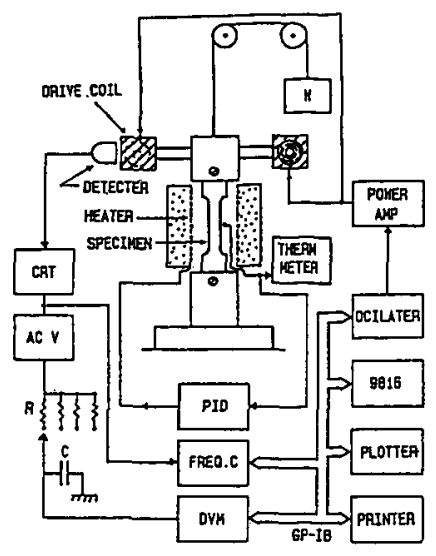

Fig.1 Internal friction measurement system.

II 試料および実験方法

一般に $\mathrm{Si}_{3} \mathrm{~N}_{4}$ 燒結体の高温特性は液相の生じる温度と 密接な関係があると考えられることから $\mathrm{Y}_{2} \mathrm{O}_{3}-\mathrm{Al}_{2} \mathrm{O}_{3}$ 系 助用で液相点の異なる 2 種の助剤組成、すなわち液相 点 $1500^{\circ} \mathrm{C}$ 組成 $\mathrm{A}\left(5 \mathrm{Wt} \%_{2} \mathrm{Y}_{3}-2 \mathrm{Wt} \% \mathrm{Al}_{2} \mathrm{O}_{3}-3 \mathrm{wt} \% \mathrm{SiO}_{2}\right)$ お よび $1630^{\circ} \mathrm{C}$ 組成B ( $8 \mathrm{wt} \% \mathrm{Y}_{2} \mathrm{O}_{3}-2 \mathrm{wt} \% \mathrm{Al}_{2} \mathrm{O}_{3}-3 \mathrm{wt} \% \mathrm{SiO}_{2}$ ) の焼結体を検討した。焼結体の作製にあたっては

$\times \mathrm{LO}^{-3}$

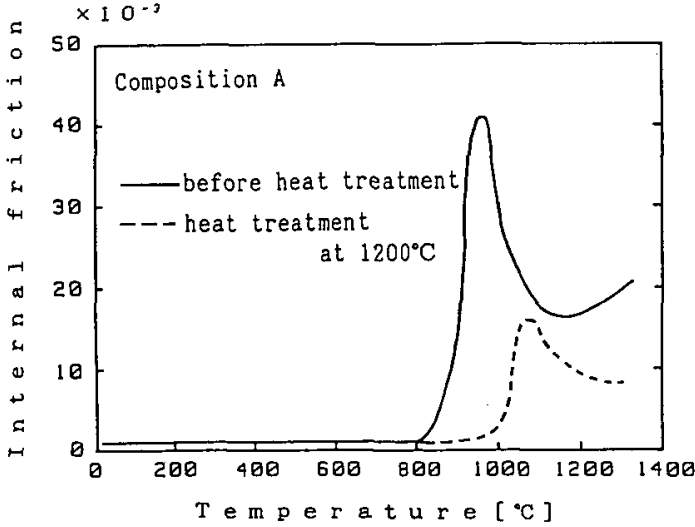

Fig. 2 Change of internal friction of composition A-specimen before and after heat treatment.

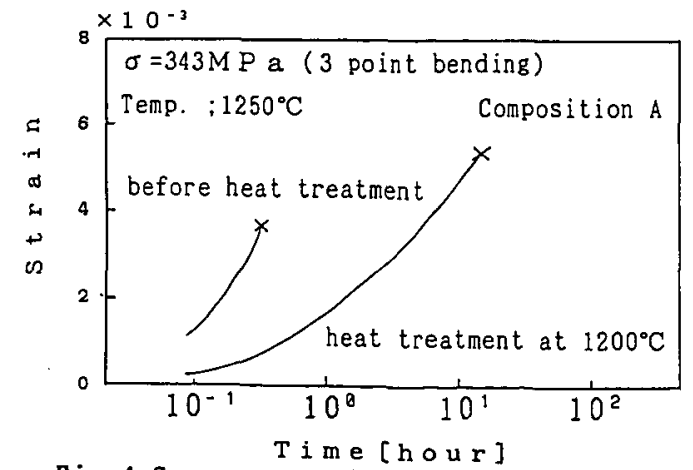

Fig. 4 Creep property of composition A-specimen before and after heat treatment.
$\mathrm{Si}_{3} \mathrm{~N}_{4}$ 粉末に目的の組成になるように $\mathrm{Y}_{2} \mathrm{O}_{3}$ 粉末、 $\mathrm{Al}_{2} \mathrm{O}_{3}$ 粉末を添加しボールミルを用いて混合した後、㛙結を 行なった。その後、焼結体の化学分析を行ない所定の 組成であることを確認した。また、焼結体の粒界相を

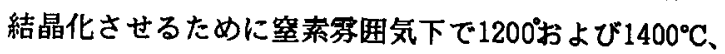

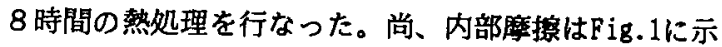
すねじり振動法”゙によて湘定し、室温か $51300^{\circ} \mathrm{C} に$ 対して、周波数約 $21 \mathrm{~Hz} て ゙$ 行なった。クリーブ試験は J I S 規格の試験片を作製し、スバン $30 \mathrm{~mm}$ の 3 点曲げに より行なった。試験条件としては大気中、荷重343MPa、 温度 $1250^{\circ} \mathrm{C}$ 、試験時間200時間とした。また、粒界相の 組織観察には透過型電子顕微鏡を用い、結晶相の同定 はX線回折により行なった。

\section{III 実験結果および考察}

\section{1 内部摩擦と高温特性の関係}

助剂組成 $\mathrm{A} 、 \mathrm{~B}$ 有する各焼結体について熱処理前 後における内部摩擦の温度変化をそれぞれFig.2、3に、 これらに対応する焼結体のクリープ特性をFig.4、.5に 示す。熱処理前の焼結体の内部摩擦変化を比較すると

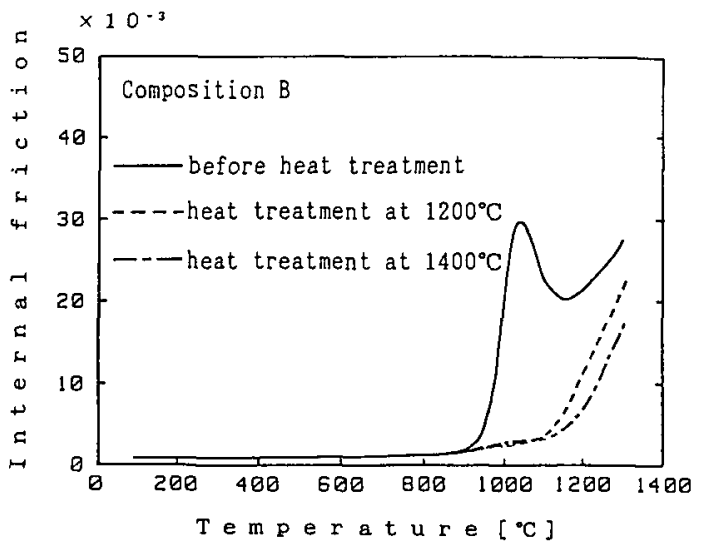

Fig. 3 Change of internal friction of composition B-specimen before and after heat treatment.

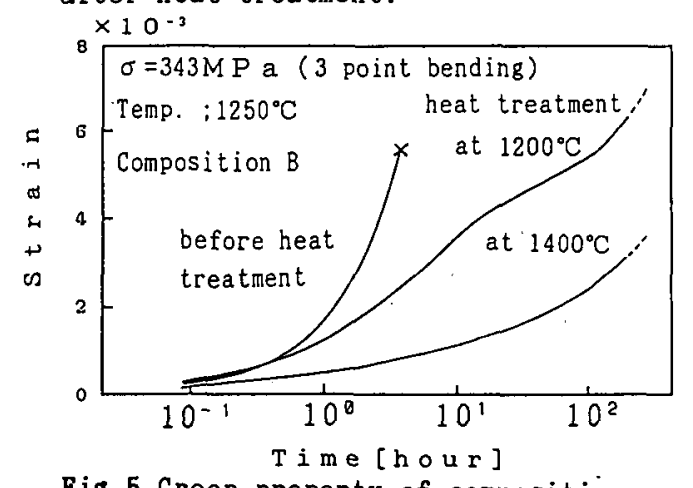

Fig.5 Creep property of composition B-specimen before and after heat treatment. 
組成A、Bのどちらにおいてもそれぞれ約 $950^{\circ} 、 1050^{\circ} \mathrm{C}$ に大きなピークが見られ、助剤組成により内部摩擦の ピークの温度が異なっている。クリーブ特性は荷重付 加後、組成 $\mathrm{A}$ のものは約20分、組成Bのものでは約4時 間で破断が起こっている。このクリーブ挙動の違いは 内部摩擦のピークの発現温度に対応しており、内部摩 擦のピークが低温側にあるものほどクリープ変形時の ひずみ速度が大きく、寿命が短い傾向がある。内部摩 擦のピークの原因となっている不安定なガラス相を消 滅 ‘させるために熱処理をした場合、Fig.2に示した組 成 $\mathrm{A} の$ 焼結体の内部摩摖変化では熱処理により明らか にピークが約 $950^{\circ}$ から約 $1050^{\circ} \mathrm{C}$ 高温側へシフトしてい る。Fig.4に示したクリープ試験の結果よると、破断ま での寿命は約20分から約14時間に変化し、内部摩摖の ピークの発現温度が高温側へシフトすることに対応し てクリープ特性が向上すると推定される。Fig.3に示し た組成 Bの焼結体の内部摩擦変化では熱処理により熱

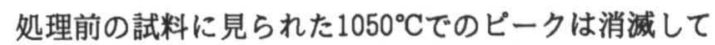
いる。ピークは熱処理温度 $1200^{\circ} 、 1400^{\circ} \mathrm{C}$ 双方とも高温 側にシフトした思われ $1100^{\circ} \mathrm{C}$ 以上の内部摩擦のベース ラインの立ち上がりのみ認められる。ベースラインの 立ち上がりの傾きの差より $1400^{\circ} \mathrm{C}$ 熱処理を行なった もののほうがピークは高温側に位置していると思われ る。Fig.5に示した $1200^{\circ} 、 1400^{\circ} \mathrm{C}$ 熱処理した試料に対 応するクリープ試験の結果から熱処理により内部摩擦 のピークが消滅した試料では200時間以上の寿命を保ち、 クリープ特性が顕著に向上しているのが認められる。 また、熱処理温度によりひずみの変化率に差が見られ、 高温特性に違いがあることがわかる。これらのことか ら低温の内部摩擦のピークを消滅させ、また高温 ( $1100^{\circ} \mathrm{C}$ 以上) での立ち上がりをさらに高温側にシフト する材料設計すなわち粒界組成、熱処理条件の決定に よりクリーブ特性を改善できると考えられる。

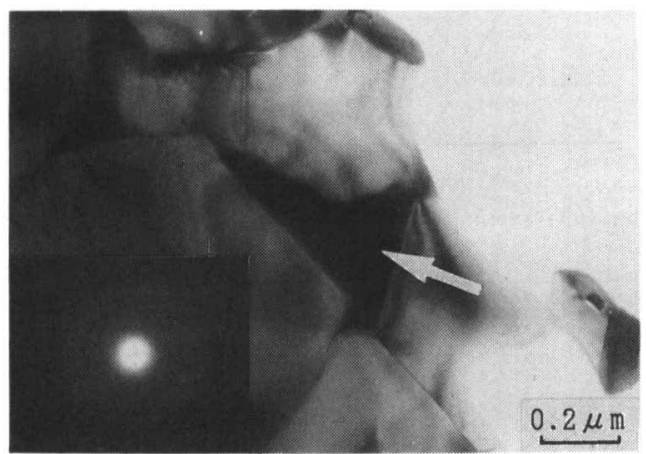

Photo.1 TBM image of composition B-specimen before heat treatment.
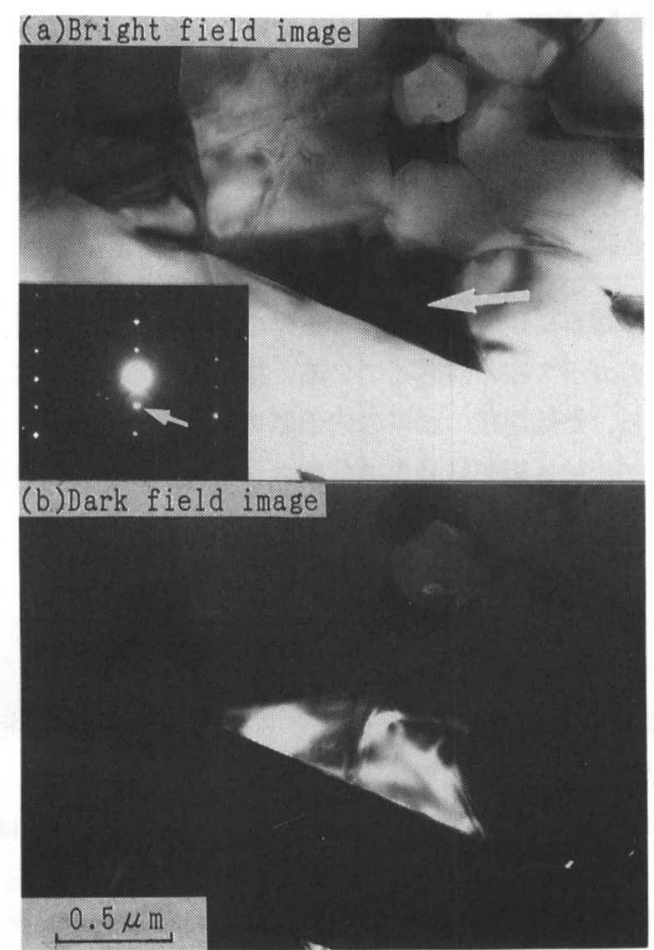

Photo.2 TEM images of composition B-specimen after heat treatment $\left(1400^{\circ} \mathrm{C}\right)$.

((a)bright field image and (b)dark field image)

\section{2 熱処理前後における内部組織の変化}

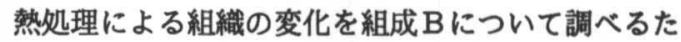
めに組成 Bの熱処理前および $1400^{\circ} \mathrm{C}$ の熱処理後の組織 を透過型電子顕微鏡で観察した。Photos.1、2に組成B を有する焼結体の熱処理前後の組織を観察した結果を 示す。明視野像で白く見える粒子が $\mathrm{Si}_{3} \mathrm{~N}_{4}$ でそのまわり に粒界相が見られる。粒界相については熱処理前後そ れぞれに対し矢印をつけた部分からの制限視野回折パ ターンをあわせて示した。これによると $\mathrm{Si}_{3} \mathrm{~N}_{4}$ 粒子の 大きさ、形には変化が見られない。一方、粒界相につ いては制限視野回折パターンに違いが見られる。 Photo.1の熱処理前の粒界相から撮つた制限視野回折パ ターンはハローパターンを示しており、ガラス構造で あることがわかる。それに対してPhoto.2に示すように $1400^{\circ} \mathrm{C}$ で熱処理後の試料の粒界相から撮った制限視野 回折パターンはスポット状になっており、完全に結晶 化していることがわかる。Photo.2(b)には回折パター ンの印をつけたスポットからの反射による暗視野像を 示したが、粒界相のみが光っていることから、粒界 3 重点全体が結晶化していることが確認される。以上の 結果、組成 $\mathrm{B}$ につて $1400^{\circ} \mathrm{C}$ 熱処理によりガラス構 造の粒界相は結晶化することが認められ、また、熱処 
Table 1 Grain boundary crystalline phases in heat-treated specimens.

\begin{tabular}{|l|c|c|}
\hline & Composition A & Composition B \\
\hline $1200^{\circ} \mathrm{C}$ heat treatment & $Y_{2} \mathrm{O}_{3} \cdot \mathrm{SiO}_{2}\left(X_{2}\right)$ & $Y_{2} \mathrm{O}_{3} \cdot \mathrm{SiO}_{2}\left(X_{2}\right), \mathrm{YSiO}_{2} \mathrm{~N}$ \\
$1400^{\circ} \mathrm{C}$ heat treatment & $\mathrm{Y}_{2} \mathrm{O}_{3} \cdot \mathrm{SiO}_{2}\left(X_{2}\right)$ & $\mathrm{Y}_{2} \mathrm{O}_{3} \cdot \mathrm{SiO}_{2}\left(X_{2}\right), \mathrm{YSiO}_{2} \mathrm{NI}$ \\
\hline
\end{tabular}

理前の試料に現われる $1000^{\circ} \mathrm{C}$ 付近の内部摩撩ピークは 粒界のガラス相に対応していると推定される。このこ とから、熱処理後の試料の内部摩擦を測定することに よって、粒界相の結晶化の状態さらにはクリーブ特性 を予測できることが確認される。

3. 3 結晶化におよぼす助剤組成の影筫

次にX線回折により組成 A、Bを有する焼結体の熱 処理後における試料の粒界析出相を調べた結果を

Table 1に示す。組成A、Bのどちらにおいても析出相 が認められ、結晶化が起こっていることが確認される。 しかしながら、Fig.2に示したように組成Aのものでは 熱処理後もガラス相が原因と考元られる約 $1050^{\circ} \mathrm{C}$ の内 部摩擦のピークが見られ、ガラス相の残存が示唆され

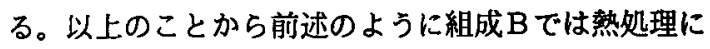

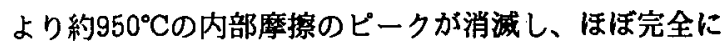
結晶化していると考えられるのに対し、組成Aでは結 晶化が不完全でありガラス相が残留しているものと推 定される。

この理由を次のように考察した。助冎組成A、Bは 3 元平衡状態図（Fig.6）においてO明に位䈯する。結 晶化させた粒界相にAlが含まれていないことから、焼 結後には助㓮の $\mathrm{Al}_{2} \mathrm{O}_{3}$ が $\mathrm{Si}_{3} \mathrm{~N}_{4}$ 粒子中に全て固溶すると 仮定すると、粒界相は $\mathrm{Y}_{2} \mathrm{O}_{3}$ と $\mathrm{SiO}_{2}$ で構成され、状態図 中の@印の組成になっていると考えられる。これらの 組成は $\mathrm{Y}_{2} \mathrm{O}_{3}-\mathrm{SiO}_{2}$ 系平衡状態図 (Fig.7) では矢印（組 成 $a 、 b ） に$ 位置する。ところで、組成 a の助用が相 分離する時に $\mathrm{Y}_{2} \mathrm{O}_{3} \cdot \mathrm{SiO}_{2}$ 相が析出した場合、組成のバラ ンスをとるためには $\mathrm{SiO}_{2}$ が析出しなければならないが X線回折では確認されていない。このことから $\mathrm{SiO}_{2}$ は 熱処理を施しても容易には析出結晶化せずにガラス相 として残存し4'内部摩擦のピークを引き起こしている と考えられる。一方、組成 b の助郕が相分離する場合 $\mathrm{Y}_{2} \mathrm{O}_{3} \cdot \mathrm{SiO}_{2}$ 相と $\mathrm{Y}_{2} \mathrm{O}_{3} \cdot 2 \mathrm{SiO}_{2}$ 相の 2 相となる。今回の熟処 理の結果ではTable 1に示したように $\mathrm{Y}_{2} \mathrm{O}_{3} \cdot \mathrm{SiO}_{2}$ 相と $\mathrm{YSiO}_{2} \mathrm{~N}$ 相が析出している。Y $\mathrm{YSiO}_{2} \mathrm{~N}$ 相は $\mathrm{Y}_{2} \mathrm{O}_{3} \cdot 2 \mathrm{SiO}_{2}$ 相と Y、Siのモル比は同じものであり、酸素の格子位置の一 部が空素で置き変わった構造と考えると、 $\mathrm{Y}_{2} \mathrm{O}_{3} \cdot \mathrm{SiO}_{2}$ 相 と $\mathrm{YSiO}_{2} \mathrm{~N}$ 相の 2 相で組成的にバランスをとることが可
能となり、2 相の結晶化が進んだものと考元られる。 以上のように熱処理の効果は助剤組成により異なり、 適正な粒界組成を設計することによって粒界相をほほ 完全に結晶化できると考えられる。

\section{4 クリーブ変形後の焼結体観察}

Photo.3に組成 B の焼結体に窒索票囲気下 $1400^{\circ} \mathrm{C} 、 8$ 時間で熱処理を施し粒界相を完全に結晶化させた試料 を用いて、1 $1250^{\circ} \mathrm{C} て ゙ 200$ 時間のクリーブ試験を行なった 後の内部組織について透過型電子顕微鏡により観察を 行った結果を示す。写真中の白い部分は $\mathrm{Si}_{3} \mathrm{~N}_{4}$ の粒子で ある。その $\mathrm{Si}_{3} \mathrm{~N}_{4}$ 粒子と右上部の粒界相との境界部から $\mathrm{Si}_{3} \mathrm{~N}_{4}$ 粒子の内部に向かって転位が発生しているのが認 められる。この転位はクリーブ試験を行なう前の試料 には観察されておらず、クリープ試験中に変形が進む

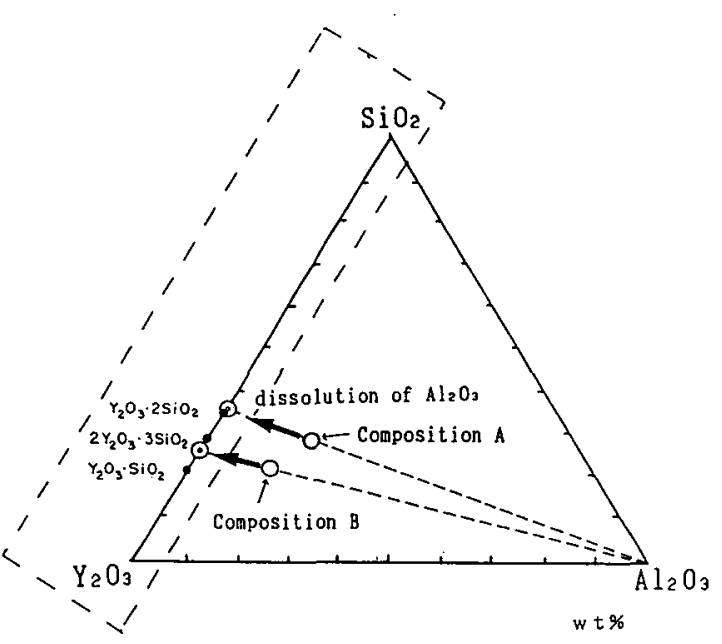

Fig. 6 Change of aids composition in $\mathrm{Y}_{2} \mathrm{O}_{3}-\mathrm{Al}_{2} \mathrm{O}_{3}-\mathrm{SiO}_{2}$ phase diagram.

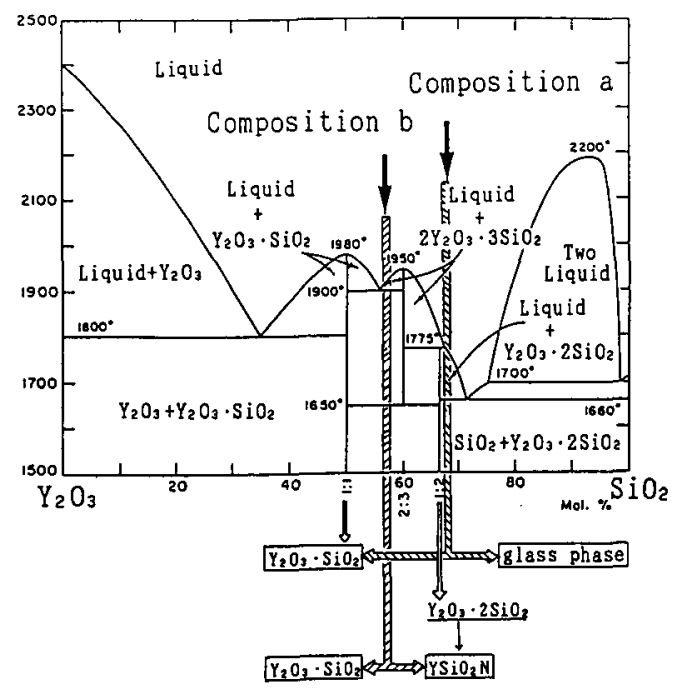

Fig. $7 \mathrm{Y}_{2} \mathrm{O}_{3}-\mathrm{SiO}_{2}$ phase diagram. 


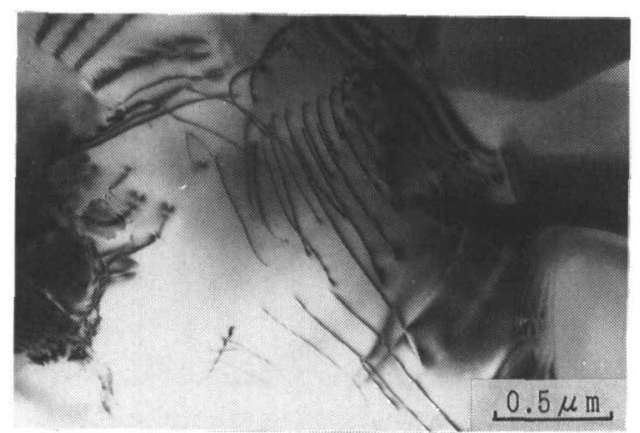

Photo.3 TBM image of heat-treated composition B-specimen after creep test. $\left(\sigma=343 \mathrm{MPa}, 1250^{\circ} \mathrm{C}\right)$

のに従って発生し移動したもの考えられる。一般に $\mathrm{Si}_{3} \mathrm{~N}_{4}$ の焼結体が高温でクリーブ変形する場合、粒界相 が軟化することにより $\mathrm{Si}_{3} \mathrm{~N}_{4}$ 粒子間で粒界すべりを起こ し進行する ${ }^{5-6)}$ ものとされ、 $\mathrm{Si}_{3} \mathrm{~N}_{4}$ 粒子内での転位の発 生・移動は $1400^{\circ} \mathrm{C}$ 以下では起こらない ${ }^{\top)}$ と報告されて いる。しかしながら、今回のように適切な助剤組成選 択と熱処理により粒界相を完全に結晶化させた場合、 粒界すべりだけでなく $\mathrm{Si}_{3} \mathrm{~N}_{4}$ 粒子内の転位の運動を伴っ た $\mathrm{Si}_{3} \mathrm{~N}_{4}$ 粒子自身の変形も同時に起こっていることが考 えられる。

\section{5 開発材料の高温特性}

内部摩摖の温度変化の測定結果を用いた粒界組成、 熱処理条件の適正化（窒素雾囲気下 $1400^{\circ} \mathrm{C} 、 8$ 時間） による材料設計を行なった $\mathrm{Si}_{3} \mathrm{~N}_{4}$ 焼結体の高温クリープ 特性をFig.8に示す。大気中、 $1250^{\circ} \mathrm{C} \cdot 343 \mathrm{MPa}$ において 200時間まで破断を起こさず、定常クリープ領域におい て歪速度 (約2.8 $\times 10^{-7} \mathrm{~min}^{-1}$ ) の小さい焼結体であるこ とが確認される。

$$
\text { IV まとめ }
$$

(1) $\mathrm{Si}_{3} \mathrm{~N}_{4}$ 焼結体の高温内部摩摖ピークは粒界相の結 晶化の進行に伴って縮小および高温側への移動を示す ことから、内部摩摖測定により粒界ガラス相の存在が

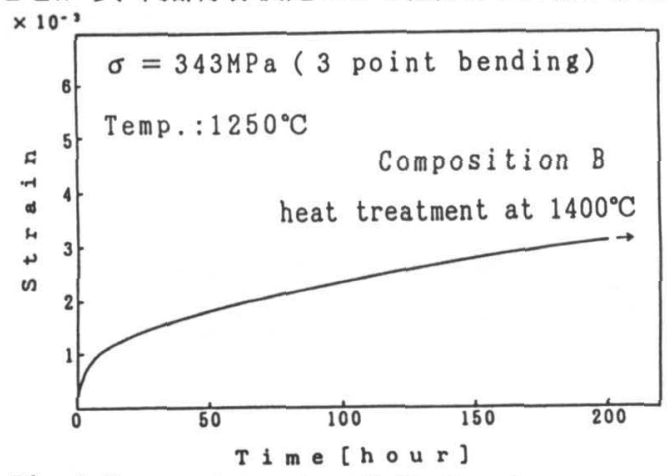

Fig. 8 Creep property of $\mathrm{Si}_{3} \mathrm{~N}_{4}$ sintered body.
大きな影翼を与えるクリープ特性を予測できることが わかった。

（2）粒界相として存在するガラス相の熱処理による 結晶化挙動は助剂組成によって異なり、適切な助剂組 成の選択により粒界のガラス相を完全に結晶化するこ とが可能である。

（３）粒界相を完全に結晶化させた焼結体ではクリー プ試験後の $\mathrm{Si}_{3} \mathrm{~N}_{4}$ 粒子内で転位の発生・移動が観察され、 クリープ変形には従来報告されている粒界すべりに加 えて $\mathrm{Si}_{3} \mathrm{~N}_{4}$ 粒子のすべりを伴った塑性変形が関与してい る可能性が見いだされた。

(4) 内部摩擦の温度変化の測定結果を用いて粒界組 成、熱処理条件の適正化を行ない高温クリーブ特性に 優れた $\mathrm{Si}_{3} \mathrm{~N}_{4}$ 焼結体を作製することができた。

本研究は、通産省工業技術院の次世代産業基盤技術 研究開発制度に基づき、ファインセラミックス技術研 究組合が新エネルギー・産業技術総合開発機構 ( N E D O ）から委託をうけた「石炭ガス化用セラミックス タービンの要素技術開発」の一環として行なわれたも のである。

謝辞

本研究の内部摩摖については大阪大学産業科学研究 所 松下健一技官にご指導頂きました。厚く謝意を表 します。

\section{文献}

1)A.Tsuge, K.Nishida: Am.Ceram.Soc.Bull., $57(1978) 424$.

2)松下 健一、岡本 平:日本セラミックス協会第27回 セラミックス基礎科学討論会講演要旨集, 1989 , p. 187 .

3)M.K.Cinibulk, G.Thomas, S.M.Johnson: J.Am. Ceram.Soc., 73(1990), 1606.

4)W.D.Kingery, H.K.Bowen, D.R.Uhlmann: 小松 和藏、 佐多 敏之、守吉 佑介、北澤 宏一、植松 敬三 共訳 “セラミック材料科学入門”, 内田老鶴罟, 1980 , p. 339 .

5)J.A.Todd, Z.-Y.Xu: J.Mater.Sci., 24(1989), 4443.

6)幾原 雄一、陶山 容子:日本セラミックス協会 1990年会講演予稿集, 1990, p. 461 .

7)R.Kossowsky, D.G.Miller, B.S.Diaz: J.Mater . Sci., 10(1975),983. 